\title{
Попова-Щербакова Л.В. \\ Отношение молодёжи Южного федерального округа к терроризму и экстремизму
}

В статье проводится анализ явлений терроризма и экстремизма в Южном федеральном округе, приводятся результаты исследования по опроснику в виде незаконченных предложений «Отношение к экстремизму и терроризму», проведенному среди участников антитеррористического фестиваля студенческой, научной и творческой молодежи «Мир Кавказу».

Ключевые слова: экстремизм, терроризм, представление молодёжи об этих явлениях, представления о причинах и способах борьбы с экстремизмом и терроризмом.

В настоящее время современное российское общество переживает трансформацию системы ценностей, обусловленную модернизацией общественной жизни. Процессы глобализации в экономической, политической, культурной сферах, втягивающие население разных стран в миграционные потоки разного характера и уровня приводят к усложнению структурных связей конкретных обществ и всего сообщества в целом. Вышеперечисленные факторы в определенной степени стимулируют напряженность в межнациональных отношениях, сопровождающуюся межэтническими конфликтами, начинают появляться различные оппозиционные группы, добивающиеся желаемого результата через экстремизм и терроризм. Особенно это актуально для нашего многонационального и многоконфессионального Северного Кавказа.

Южный федеральный округ является не только самым многонациональным регионом нашей страны, но и отличается сложной конфессиональной картиной. Здесь зарегистрировано более 3300 религиозных организаций. Конфессиональное пространство региона можно условно разделить на четыре основные части: 40 \% - религиозные организации Русской православной церкви (РПЦ); 30 \% - религиозные организации мусульман; 27 \% - протестантские организации и 3 \% - буддисты и иудеи. Исламские организации преобладают в 5 субъектах ЮФО (Дагестан, Ингушетия, КЧР, КБР и Чечня). На Юге России действуют 11 Духовных управлений мусульман (ДУМ), большинство из которых входят в Координационный центр мусульман Северного Кавказа (КЦМСК). Самое крупное региональное Духовное управление мусульман зарегистрировано в Дагестане, где действуют 1756 мечетей. ДУМ Чечни объединяет около 300 мечетей, Ингушетии - 85, Северной Осетии - 19, 
Кабардино-Балкарии - 130, Карачаево-Черкесии и Ставропольского края 113, Адыгеи и Краснодарского края - 28, Ростовской области - 17, Калмыкии 2. В регионе значительное развитие получило исламское образование. На Юге России официально действуют 30 исламских вузов, из которых 19 в Дагестане, 8 в Чечне и по одному в Кабардино-Балкарии, КарачаевоЧеркесии и Астраханской области. В то же время более 2500 молодых людей из субъектов ЮФО обучаются в зарубежных исламских учебных заведениях. Еще одна специфика религиозной ситуации в регионе - большое количество мусульман, совершающих паломничество - умра и хадж. Так, если в 2006 г. из Российской Федерации совершили паломничество в КСА более 15,5 тыс. чел., то более 14,5 тысяч человек из них были из субъектов Юга России. На Северный Кавказ религиозно-политический экстремизм и терроризм активно начинает проникать около двадцати лет тому назад, в первую очередь на территорию Дагестана и Чечни. Одним из важных факторов геополитического характера распространения исламского радикализма на Северном Кавказе является разносторонняя поддержка их деятельности извне многочисленными международными радикальными исламскими центрами, зарубежными культурно-просветительскими и благотворительными организациями. Так, с конца 80-х - до 1999 г. на Северном Кавказе действовали филиалы международных благотворительных, просветительских, культурных организаций. За эти же годы активизировалась деятельность таких исламских организаций, как Международная исламская организация «Спасение» (МИОС), «Беневоленс Интернешнл Фаундейшн»» (БИФ, штаб-квартира расположена в г. Чикаго, США), «Джамаат Ихья Ат-Турас Аль-Ислами» (штаб-квартира в Кувейте), «Лашкар Тайба» (штаб-квартира в Пакистане), «Аль-Хайрия», «Аль-Харамейн» («AL-Haramein Foundation» (образовательный центр в США), «Катар» (штаб квартира в Катаре), «Икраа» (штаб-квартира в Джидде (КСА), «Ибрагим бен Ибрагим» (штаб-квартира в Джидде (КСА) и др., финансируемых и направляемых Саудовской Аравией, Пакистаном, Кувейтом. Для них характерны практически открытая пропаганда панисламистских идей объединения всех мусульман региона для вытеснения России с Северного Кавказа, создания в северокавказском регионе исламского государства, за установление тесных связей Северного Кавказа, Дагестана с такими мусульманскими странами, как Саудовская Аравия, Турция, Иран, Иордания, Пакистан. По решению северокавказских судов в 1999-2000 гг. все они за активную поддержку, в том числе и финансирование исламских радикальных группировок и организаций в Дагестане, были закрыты. Исламские радикальные структуры в Южном федеральном округе тесно связаны с радикальными исламистскими 
организациями за рубежом, за которыми просматриваются геополитические интересы, как государств исламского мира, так и ряда западных держав. Специальные службы и неправительственные организации этих стран стремятся обеспечить благоприятные условия для оказания выгодного им воздействия на развитие политической, экономической и религиозной ситуации в регионе в целом. Они рассматривают Дагестан в качестве плацдарма для утверждения своего духовного и политического влияния на Северном Кавказе и других мусульманских регионах России. Привнесенный в нашу страну с конца 80-х гг. XX в. при мощной финансовой и организационной поддержке из-за рубежа идеология религиозно-политического экстремизма стала агрессивной идеологией, питающей идеи радикального национализма и сепаратизма для целей, далеких от нужд абсолютного большинства мусульман Юга России. Религиозно-политический экстремизм и терроризм на Юге России представлен в основном в виде ваххабизма. Исторически ваххабизм представляет собой фундаменталистское религиозное движение в суннитском исламе, ставшее идейным столпом будущего саудовского государства. Сложность и неоднозначность самого феномена исламского радикализма в мире, в том числе и в России и на Северном Кавказе привела к тому, что на официальном уровне, на языке представителей науки, средств массовой информации, специалистов и, наконец, официального духовенства стали широко использовать многочисленные определения, такие, как «ваххабиты», «последователи ваххабизма», «салафиты», «фундаменталисты», «муваххидун», «джамаатисты», «исламские экстремисты» и многие другие. Отдельные исследователи (директор Института религии и права, профессор МГУ А. Игнатенко) считают, что более точное и научное определение этого феномена - «ваххабизм». Термин «ал-ваххабийа» («ваххабизм») прочно утвердился и в мусульманском мире. Как показывает анализ деятельности сторонников религиозно-политического экстремизма на постсоветском пространстве, они стремятся путем демагогии, организации беспорядков, актов гражданского неповиновения дестабилизировать и разрушить существующие общественные структуры для достижения своих целей. При этом широко используют силовые методы - террористические акты, партизанскую войну и т.д.; в принципе отрицают переговоры, соглашения, компромиссы, основанные на взаимных уступках. Мы живем в сложном и постоянно меняющемся мире, в котором проблема национального, этнического, социального и политического экстремизма стоит особенно остро. Мы каждый день слышим о все новых и новых случаях ксенофобии и национализма, главным участником которых является молодежь как слой, наиболее остро 
и чутко реагирующий на все изменения общества. В XXI веке экстремизм и терроризм, как его крайняя форма, превратились в одну из самых сложных социальных проблем, став частью политики и инструментом проведения внешнеполитической деятельности для достижения геополитических целей отдельных держав, сил и движений на мировой арене.

В своей статье мы придерживаемся следующих определений. Экстремизм это приверженность отдельных лиц, групп, организаций и т.п. к крайним взглядам, позициям и мерам в общественной деятельности. Экстремизм распространяется как на сферу общественного сознания, общественной психологии, морали, идеологии, так и на отношения между социальными группами (социальный экстремизм), этносами (этнический или национальный экстремизм), общественными объединениями, политическими партиями, государствами (политический экстремизм), конфессиями (религиозный экстремизм).

Политическая практика экстремизма находит выражение в различных формах экстремистской деятельности, начиная от проявлений, не выходящих за конституционные рамки, и заканчивая такими острыми и общественно опасными формами как мятеж, повстанческая деятельность, терроризм.

Терроризм - сложное социально-политическое и криминальное явление, обусловленное внутренними и внешними противоречиями общественного развития различных стран. Представляет собой многоплановую угрозу для жизненно важных интересов личности, общества и государства, одну из наиболее опасных разновидностей политического экстремизма в глобальном и региональном масштабах.

По своей социально-политической сущности терроризм представляет собой систематическое, социально или политически мотивированное, идеологически обоснованное применение насилия, либо угроз применения такового, посредством которого через устрашение физических лиц осуществляется управление их поведением в выгодном для террористов направлении и достигаются преследуемые террористами цели.

Терроризм включает несколько взаимосвязанных элементов: идеологию терроризма (теории, концепции, идейно-политические платформы); террористические структуры (международные и национальные террористические организации, экстремистские - правые и левые, националистические, религиозные и другие общественные организации, структуры организованной преступности и т.п.), а также собственно террористическую практику (террористическую деятельность).

Для того, чтобы эффективно бороться с данными явлениями, необходимо, прежде всего, изучить природу экстремизма, понять, почему люди идут 
в экстремистские группировки. Существует большое количество литературы, посвященной исследованию проблемы экстремизма и терроризма, но еще больше необходимо исследовать.

Наше исследование, проведенное среди участников антитеррористического фестиваля студенческой, научной и творческой молодежи «Мир Кавказу» (Ростов-на-Дону, 12-15 сентября 2010 г.), было направлено на выявление причин экстремизма и терроризма, а также представлений участников о том, какими способами можно и необходимо бороться с ними.

В исследовании приняли участие 95 человек, из них 90 \% - молодёжь (студенты и молодые ученые ЮФО различной конфессиональной принадлежности). Они заполняли опросник в виде незаконченных предложений «Отношение к экстремизму и терроризму», из которого мы проанализируем ответы о причинах, по которым люди вступают в эктремистские группировки, а также мнение участников фестиваля о том, какими способами необходимо бороться с экстремизмом и терроризмом.

В результате анализа мы получили следующие данные.

1. Причины, по которым люди вступают в экстремистские группировки, можно разделить на три группы:

2. психологические причины (личностные качества, психические расстройства, внушаемость, болезненное восприятие реальности, непонимание, несамореализованность и т.п.) отметили 53,2 \% респондентов;

-социальные причины (низкий уровень жизни, слабая экономическая развитость стран, безработица, отсутствие антипропаганды терроризма и экстремизма и т.п.) отметили $24,7 \%$;

-религиозные причины (разные религиозные ценности, религия по принуждению, отсутствие настоящей веры и т.п.) отметили $22,1 \%$.

3. Предлагаемые способы борьбы с экстремизмом и терроризмом также можно разделить на три группы:

1) радикальные меры борьбы с экстремизмом и терроризмом (ввести публичную казнь, истребить всех террористов, уничтожать поселения и т.п.) - 26,2 \% респондентов;

2) социальные меры борьбы с экстремизмом и терроризмом (улучшить экономическую сторону жизни, проводить различные антитеррористические акции и т.п.) - 32,3\%;

3) психолого-педагогические меры (проводить воспитательные беседы, начиная с младшего школьного возраста, развивать в людях терпение друг к другу, быть терпимыми друг к другу, воспитывать дух товарищества, патриотизм и т.п.) $-41.5 \%$ респондентов. 
Итак, в результате анализа проведенного исследования можно сделать вывод о том, что надо не только бороться с экстремистской деятельностью, но, в первую очередь, проводить профилактику в виде реализации комплексной системы политических, социально-экономических, информационных, воспитательныхи т.п. мер, направленных на установление и устранение причин и условий экстремизма.

\section{Литература}

1. Антонян Ю.М., Давитадзе М.Д. Этнорелигиозные конфликты: проблемы, решения. - М., 2004.

2. Борьба с экстремизмом: методологические основы и состояние // Актуальные проблемы национальной безопасности России на современном этапе / Аналитический вестник Совета Федерации ФС РФ. - 2004. - № 1.

3. Верховский А. Противодействие национал-экстремизму: проблема и актуальные варианты решения // Антисемитизм и ксенофобия в Российской Федерации. 2002. - № 11.

4. Володина Н.В. Особенности экстремизма на религиозной почве // Безопасность Евразии. - № 3.

5. Гафарлы М. Как бороться с религиозным экстремизмом // Независимая газ. 1999.

6. Горишний К.В. Факторы современного этнического экстремизма на примере Северного Кавказа // Журнал научных публикаций аспирантов и докторантов. - 2008. - № 3.

7. Гриб Н.Н. Информационно-психологическая сфера как ведущее звено системы противодействия терроризму // Российский следователь. - 2004. - № 6.

8. Диль В.А. Тенденции развития современного экстремизма: молодежный и информационный экстремизм //Известия Томского политехнического университета. - 2009. - Т. 314. - № 6. - С. 167-170.

9. Добаев И.П. Опасность исламизации и этнизации общества на Юге России // http:||www.rusk.ru|st.php?idar=20436 (дата посещения 18.10.2010).

10. Дробижиева Л., Паи Э. Политический экстремизм и терроризм: социальные корни проблемы // Век толерантности. - № 5.

11. Емельянов В.П. Терроризм и преступления с признаками терроризирования. М., 2000.

12. Жээнбеков Э.Т. Профилактические меры противодействия религиозному экстремизму // Российский следователь. - 2006. - № 7.

13. Зуев А. Средства массовой информации и проблемы межэтнических взаимоотношений. - Саратов, 2006. - С. 4.

14. Ляхов Е.Г., Попов А.В. Терроризм: национальный, региональный и международный контроль. - Ростов-на-Дону, 1999. 
15. Ольшанский Д.В. Психология террора. - М., Академический проект: ОППЛ; Екатеринбург: Деловая книга, 2002.

16. Павлинов А.В. Насильственный экстремизм. - М., 2004.

17. Чарный С., Степанищев С. Расизм, ксенофобия, неонацизм в регионах РФ // http://index.org.ru (дата посещения 18.10.2010). 